\title{
Metode Pengukuran Kapasitansi Dengan Menggunakan Mikrokontroler Arduino Uno
}

\author{
Valentinus Galih Vidia Putra*, Andrian Wijayono, Endah Purnomosari, Ngadiono, dan \\ Irwan \\ Laboratorium Fisika-Mekatronika, Politeknik STTT Bandung, \\ Jalan Jakarta No.31 Bandung. 40272. Indonesia \\ *E-mail: valentinus@kemenperin.go.id
}

\begin{abstract}
Abstrak
Rangkaian RC (Resistor-Kapasitor) adalah suatu rangkaian listrik yang memiliki kombinasi komponen resistor dan kapasitor yang biasanya dipasang secara seri atau sejajar. Penelitian ini dilakukan untuk menghitung nilai kapasitansi pada dua kapasitor dengan kapasitansi yang berbeda dan satu resistor yang sama, selain itu penelitian ini bertujuan untuk membandingkan hasil eksperimen dan teori dengan menggunakan sistem akuisi data. Pengukuran kapasitansi dilakukan secara eksperimen menggunakan Arduino Uno dan dilakukan pada tegangan maksimum 5 volt. Pada penelitian ini, telah berhasil ditentukan jumlah kapasitansi muatan pada kapasitor, serta telah berhasil dibandingkan kapasitansi muatan pada kapasitor secara eksperimen dan prediksi teori. Pada penelitian ini didapatkan kesesuaian hasil antara eksperimen dan teori (nilai $\mathrm{R}^{2}$ pada pengisian dan pengosongan lebih besar dari 0,95).
\end{abstract}

Kata kunci: Resistor, Kapasitor, Charged, Discharged.

\begin{abstract}
$R C$ circuit (Resistor-Capacitor) is an electric circuit that has a combination of resistor and capacitor components which are installed either series or parallel. This research was conducted to measure the capacitance of two capacitors with different capacitances with only using one resistor. This study aims to compare the capacitance both experimentally (using data acquisition systems) and theoretically. Capacitance measurements were carried out experimentally using Arduino Uno and at a maximum voltage of 5 volts. In this research, it has been successfully determined the charge capacitance of the capacitors, both in experiment and theory. It has been found the correlation of the results between experiment and theory (the value of $R^{2}$ in charging and discharging process is greater than 0.95).
\end{abstract}

Keywords: Resistor, Capacitor, Charged, Discharged.

\section{PENDAHULUAN}

Akuisisi data yaitu suatu prinsip mendapatkan atau mengambil data untuk diproses menjadi suatu informasi yang dikehendaki (Arshad, Khan, Alam, Tasnim, Gunawan, Ahmad, \& Nataraj, 2016). Penelitian mengenai akuisisi data kapasitor telah menjadi hal yang penting dan telah dilakukan oleh para peneliti (Laflamme, Saleem, Vasan, Geiger, Chen, Kessler, \& Rajan, 2013 \& Laflamme, Ubertini, Saleem, D'Alessandro, Downey,
Ceylan, \& Materazzi, 2015).

Peristiwa pengisian dan pengosongan muatan kapasitor memegang peranan penting dalam elektronika (Halliday, Resnick, Walker, 1997). Selain fungsi pada umumnya, contoh sistem kapasitansi lainnya juga digunakan untuk prinsip activity monitoring (Arshad, dkk 2016), untuk pengukuran kapasitansi graphene (Xia dkk, 2009), serta pada sistem sensor humidity (Kondalkar, dkk 2019). Prinsip kapasitor bahkan hari ini telah diaplikasikan pada penggunaan sensor di bidang health monitoring (Mukhopadhyay, 2015 \& Coyle, dkk 
2010). Beberapa contoh penggunaan prinsip kapasitor pada bidang health monitoring adalahi untuk kegunaan respiration sensor (Min, dkk 2014 \& Hoffmann, dkk 2011), heart rate sensor (Cheng, Amft, Bahle, \& Lukowicz, 2013 \& Lee, dkk 2015), serta sweat rate sensor (Salvo, dkk 2010). Secara umum, cara kerja perangkat kapasitor pada berbagai aplikasi terapan tersebut adalah dengan cara mendeteksi perubahan kapasitansi yang terjadi. pengukuran kapasitansi pada kapasitor merupakan salah satu hal yang penting untuk diteliti. Pada perangkat kapasitor, posisi pengisian atau charge akan menghasilkan grafik tegangan yang naik hingga mencapai suatu kondisi yang stabil (Tang, dkk 2019). Pada posisi pengosongan atau discharge akan menghasilkan grafik menurun (Dean dkk, 2013). Berdasarkan hal tersebut, akuisisi data dan pengukuran kapasitansi pada kapasitor merupakan salah satu hal yang penting untuk diteliti.

Tujuan dari penelitian ini adalah menentukan suatu metode untuk mengetahui jumlah kapasitansi muatan pada kapasitor, membandingkan kapasitansi muatan pada kapasitor dengan menggunakan perangkat Arduino Uno secara eksperimen dan teori, serta mendapatkan nilai $\mathrm{R}^{2}$ pada pengujian charged dan discharged. Kesesuaian antara eksperimen dan teori dapat dilihat dari nilai perhitungan $R^{2}$ (Putra, Ngadiono dan Purnomosari, 2016)

Kapasitor adalah sebuah benda yang dapat menyimpan muatan listrik. Benda ini terdiri dari dua pelat konduktor yang dipasang berdekatan satu sama lain tapi tidak sampai bersentuhan (Allagui, Elwakil, Fouda, \& Radwan, 2018). Kapasitor dapat menyimpan tenaga listrik dan dapat menyalurkannya kembali (Halliday, dkk, 1997). Kapasitas dari sebuah kapasitor adalah perbandingan antara banyaknya muatan listrik dengan tegangan kapasitor, sesuai dengan persamaan (1) (Putra, dkk, 2016)

$$
C=Q / \Delta V
$$

Menurut Halliday, dkk (1997), besar kapasitansi dirumuskan $C=0,0885 \mathrm{~A} / \mathrm{d}$. Maka kapasitasnya dalam satuan piko farad dengan $A$ adalah luas bidang plat yang saling berhadapan dan saling mempengaruhi dalam satuan $\mathrm{cm}^{2}$ dan $d$ adalah jarak antara plat dalam satuan $\mathrm{cm}$. Bila tegangan antara plat 1 volt dan besarnya muatan listrik pada plat 1 coulomb, maka kemampuan menyimpan listriknya disebut 1 farad. Dalam kenyataannya kapasitor dibuat dengan satuan di bawah 1 farad. Kebanyakan kapasitor elektrolit dibuat mulai dari 1 mikrofarad sampai beberapa milifarad. Resistor adalah salah satu komponen elektronika yang berfungsi sebagai penahan arus yang mengalir dalam suatu rangkaian dan berupa terminal dua komponen elektronik yang menghasilkan tegangan pada terminal yang sebanding dengan arus listrik yang melewatinya sesuai dengan hukum Ohm (V=IR). (Putra, dkk, 2016).

Resistor adalah komponen elektronika pasif yang berfungsi untuk menghambat dan mengatur arus listrik dalam suatu rangkaian elektronika. (Halliday, dkk ,1997). Fungsi resistor adalah sebagai pengatur dalam membatasi jumlah arus yang mengalir dalam suatu rangkaian (Putra, dkk, 2016). Dengan adanya resistor menyebabkan arus listrik dapat disalurkan sesuai dengan kebutuhan. Adapun fungsi resistor secara lengkap yaitu :

1. Berfungsi untuk menahan sebagian arus listrik agar sesuai dengan kebutuhan suatu rangkaian elektronika (González, dkk 2019).

2. Berfungsi untuk menurunkan tegangan sesuai dengan yang dibutuhkan oleh rangkaian elektronika.

3. Berfungsi untuk membagi tegangan.

4. Berfungsi untuk membangkitkan frekuensi tinggi dan frekuensi rendah dengan bantuan transistor dan kondensator (Badamasi, 2014) .

Resistor dapat dilihat nilainya dengan melihat warna yang terdapat pada resistor tersebut, adapun warna tersebut dapat dilihat pada Tabel 1. 
Tabel 1. Kode Warna Resistor (Putra, dkk, 2016)

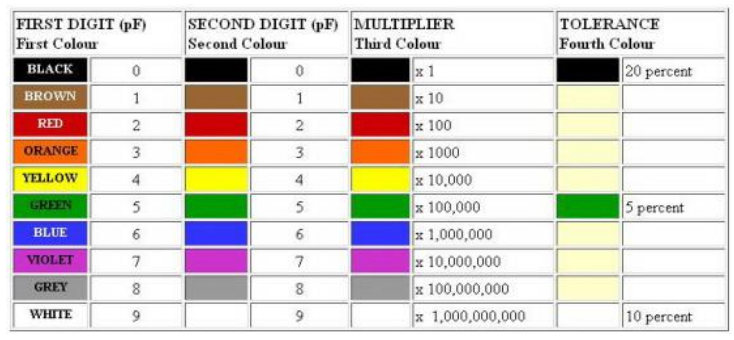

Rangkaian R-C (Pengisian Kapasitor) dapat dijelaskan sebagai berikut: Jika suatu kapasitor dalam kondisi tidak bermuatan dan pada waktu awal rangkaian dalam kondisi terbuka, maka saat switch $\mathrm{t}=0$ dalam kondisi tertutup maka kapasitor dalam kondisi dimuati maka besar tegangan antara kedua plat semakin bertambah. Saat muatan maksimum pada kapasitor tercapai, maka besar arusnya adalah nol sedangkan besar tegangannya maksimum, seperti pada Gambar 1. (Putra, dkk, 2016)

Besar arus yang terukur pada kondisi rangkaian tertutup adalah sesuai dengan persamaan (2).

$$
V=\frac{Q}{C}=\left(1-e^{-\frac{t}{R C}}\right)
$$

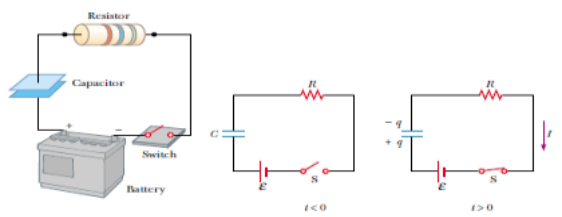

Gambar 1. Rangkaian R-C Pengisian Kapasitor (Putra, dkk, 2016)

Rangkaian R-C (Pengosongan kapasitor) dapat dijelaskan sebagai berikut: Jika rangkaian kapasitor bermuatan $Q$ dan resistor tidak dihubungkan dengan sumber tegangan atau dalam kata lain $\varepsilon=0$, sehingga sesaat rangkaian dalam kondisi tertutup, maka akan muncul arus listrik yang muncul dari kapasitor, sedangkan jumlah muatan pada kapasitor akan berkurang. (Putra, dkk, 2016)

Dengan besar tegangan kapasitor pada keadaan discharge sesuai dengan persamaan (3).

$$
V=V_{s} e^{-\frac{t}{R C}}
$$

Susunan rangkaian pada proses discharged dapat diperlihatkan seperti pada Gambar 2.

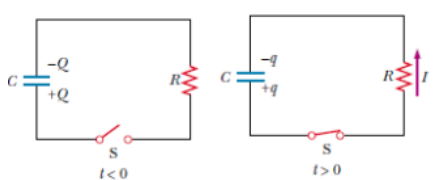

Gambar 2. Rangkaian R-C Pengosongan

Kapasitor (Putra, dkk, 2016)

\section{METODE EKSPERIMEN}

Pada metode eksperimen dijelaskan mengenai alat dan bahan, skema percobaan serta prosedur kerja.

Berikut ini merupakan Alat dan Bahan yang digunakan:

1. 1 buah Project Board

2. 1 buah Resistor $\left(10 \times 10^{3} \mathrm{ohm}\right)$

3. 1 buah Kapasitor $2200 \mu \mathrm{F}$

4. 1 buah Kapasitor $330 \mu \mathrm{F}$

5. 1 buah Komputer/Laptop

6. Kabel Penghubung

7. Arduino Uno

8. Program Arduino

9. Program MATLAB

Skema percobaan dapat diperlihatkan seperti pada Gambar 3 dan Gambar 4. Pengukuran kapasitansi menggunakan mikrokontroler Arduino Uno dapat dilihat pada Gambar 5.

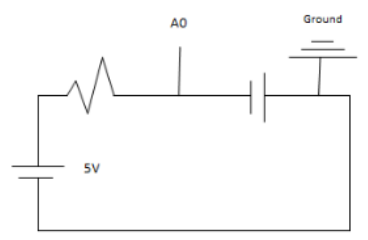

Gambar 3. Skema Rangkaian Pengisian Kapasitor

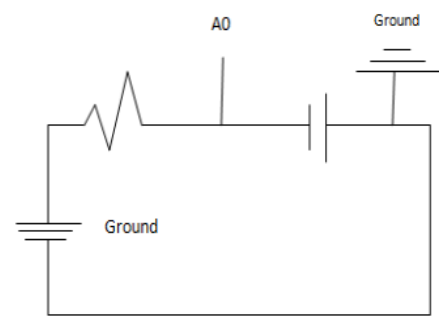

Gambar 4. Skema Rangkaian Pengosongan Kapasitor

Prosedur metode pengukuran kapasitansi dapat dijelaskan sebagai berikut:

1. Program Arduino dibuat pada komputer.

2. Resistor dan kapasitor dirangkai pada project board seperti skema di atas. 
Valentinus Galih Vidia Putra, et al

3. Arduino uno dihubungkan ke komputer.

4. Program dimasukan pada Arduino.

5. Kapasitor diisi hingga mencapai tegangan maksimum 5V atau sampai nilainya konstan.

6. Kapsitor dikosongkan dari 5V hingga OV atau nilainya sampai konstan.

7. Perhitungan dilakukan pada Microsoft Excel untuk membandingkan hasil eksperimen dan hasil teori.

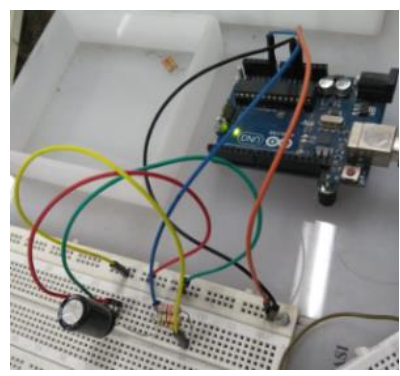

Gambar 5. Pengukuran Kapasitansi Menggunakan Mikrokontroler Arduino Uno

\section{HASIL DAN PEMBAHASAN}

Pengujian kali ini yaitu pengisian atau charging pada kapasitor $2200 \mu \mathrm{F}$ yang dilakukan dengan menghubungkan resistor pada sumber tegangan 5V. Proses ini disebut sebagai proses pengisian secara eksperimen sehingga menghasilkan tegangan eksperimen pada setiap 2 detik dari tegangan awal 0 volt hingga 5 volt yang kemudian akan dibandingkan dengan hasil prediski teori. Berikut data tegangan eksperimen yang ditunjukan pada Tabel 2.

Tabel 2 Data Eksperimen pada Pengisian Kapasitor $2200 \mu \mathrm{F}$

\begin{tabular}{|c|c|c|c|c|c|}
\hline $\begin{array}{c}\text { Charge } \\
2200\end{array}$ & $\mathrm{~T}$ & $\mathrm{~B}$ & v teori $^{(\text {vte- }}$ & $\begin{array}{c}\text { (vavg- }_{\text {vex }}^{\wedge} 2 \\
\text { vexp) }^{\wedge} 2\end{array}$ \\
\hline 0 & 0 & 0.045 & .0 .00 & 0.0000 & 18.796 \\
\hline 0.11 & 2 & 0.045 & .430 .34 & 0.1026 & 17.854 \\
\hline 0.5 & 4 & 0.045 & .823 .65 & 0.1047 & 14.710 \\
\hline 0.86 & 6 & 0.045 & 1.183 .10 & 0.1044 & 12.078 \\
\hline 1.19 & 8 & 0.045 & 1.511 .62 & 0.1034 & 9.893 \\
\hline 1.49 & 10 & 0.045 & 1.811 .86 & 0.1036 & 8.096 \\
\hline 1.76 & 12 & 0.045 & 2.086 .26 & 0.1064 & 6.633 \\
\hline 2.01 & 14 & 0.045 & 2.337 .04 & 0.1070 & 5.407 \\
\hline 2.25 & 16 & 0.045 & 2.566 .24 & 0.1000 & 4.349 \\
\hline 2.46 & 18 & 0.045 & 2.775 .71 & 0.0997 & 3.517 \\
\hline 2.65 & 20 & 0.045 & 2.967 .15 & 0.1006 & 2.841 \\
\hline
\end{tabular}

\begin{tabular}{|c|c|c|c|c|c|}
\hline $\begin{array}{c}\text { Charge } \\
2200 \\
\end{array}$ & $\mathrm{~T}$ & B & v teori & $\begin{array}{c}\text { vte- } \\
\text { vex })^{\wedge} 2\end{array}$ & $\begin{array}{l}\text { (vavg- } \\
\text { vexp)^2 }\end{array}$ \\
\hline 2.83 & 22 & 0.045 & 3.142 .12 & 0.0974 & 2.266 \\
\hline 3 & 24 & 0.045 & 3.302.02 & 0.0912 & 1.783 \\
\hline 3.15 & 26 & 0.045 & 3.448 .17 & 0.0889 & 1.405 \\
\hline 3.29 & 28 & 0.045 & 3.581 .73 & 0.0851 & 1.093 \\
\hline 3.43 & 30 & 0.045 & 3.703 .80 & 0.0750 & 0.820 \\
\hline 3.54 & 32 & 0.045 & 3.815 .36 & 0.0758 & 0.633 \\
\hline 3.66 & 34 & 0.045 & 3.917 .32 & 0.0662 & 0.456 \\
\hline 3.75 & 36 & 0.045 & 4.010 .51 & 0.0679 & 0.343 \\
\hline 3.85 & 38 & 0.045 & 4.095 .67 & 0.0604 & 0.236 \\
\hline 3.93 & 40 & 0.045 & 4.173 .51 & 0.0593 & 0.164 \\
\hline 4.01 & 42 & 0.045 & 4.244 .64 & 0.0551 & 0.106 \\
\hline 4.09 & 44 & 0.045 & 4.309 .65 & 0.0482 & 0.060 \\
\hline 4.15 & 46 & 0.045 & 4.369 .07 & 0.0480 & 0.034 \\
\hline 4.22 & 48 & 0.045 & 4.423.37 & 0.0414 & 0.013 \\
\hline 4.27 & 50 & 0.045 & 4.473 .00 & 0.0412 & 0.004 \\
\hline 4.33 & 52 & 0.045 & 4.518 .36 & 0.0355 & 0.001 \\
\hline 4.37 & 54 & 0.045 & 4.559 .82 & 0.0360 & 0.001 \\
\hline 4.42 & 56 & 0.045 & 4.597 .70 & 0.0316 & 0.007 \\
\hline 4.47 & 58 & 0.045 & 4.632 .33 & 0.0264 & 0.018 \\
\hline 4.5 & 60 & 0.045 & 4.663 .97 & 0.0269 & 0.027 \\
\hline 4.54 & 62 & 0.045 & 4.692 .89 & 0.0234 & 0.042 \\
\hline 4.57 & 64 & 0.045 & 4.719 .33 & 0.0223 & 0.055 \\
\hline 4.6 & 66 & 0.045 & 4.743 .48 & 0.0206 & 0.070 \\
\hline 4.63 & 68 & 0.045 & 4.765 .56 & 0.0184 & 0.087 \\
\hline 4.66 & 70 & 0.045 & 4.785 .74 & 0.0158 & 0.105 \\
\hline 4.68 & 72 & 0.045 & 4.804.18 & 0.0154 & 0.119 \\
\hline 4.71 & 74 & 0.045 & 4.821 .03 & 0.0123 & 0.140 \\
\hline 4.73 & 76 & 0.045 & 4.836 .44 & 0.0113 & 0.156 \\
\hline 4.75 & 78 & 0.045 & 4.850 .52 & 0.0101 & 0.172 \\
\hline 4.77 & 80 & 0.045 & 4.863 .38 & 0.0087 & 0.189 \\
\hline 4.78 & 82 & 0.045 & 4.875 .14 & 0.0091 & 0.198 \\
\hline 4.8 & 84 & 0.045 & 4.885 .89 & 0.0074 & 0.216 \\
\hline 4.81 & 86 & 0.045 & 4.895 .71 & 0.0073 & 0.225 \\
\hline 4.82 & 88 & 0.045 & 4.904 .68 & 0.0072 & 0.235 \\
\hline 4.83 & 90 & 0.045 & 4.912 .89 & 0.0069 & 0.245 \\
\hline 4.85 & 92 & 0.045 & 4.920 .39 & 0.0050 & 0.265 \\
\hline 4.85 & 94 & 0.045 & 4.927 .24 & 0.0060 & 0.265 \\
\hline 4.86 & 96 & 0.045 & 4.933 .50 & 0.0054 & 0.275 \\
\hline 4.87 & 98 & 0.045 & 4.939 .22 & 0.0048 & 0.286 \\
\hline 4.88 & 100 & 0.045 & 4.944 .46 & 0.0042 & 0.297 \\
\hline 4.89 & 102 & 0.045 & 4.949 .24 & 0.0035 & 0.308 \\
\hline 4.9 & 104 & 0.045 & 4.953 .60 & 0.0029 & 0.319 \\
\hline 4.91 & 106 & 0.045 & 4.957 .60 & 0.0023 & 0.330 \\
\hline 4.91 & 108 & 0.045 & 4.961 .25 & 0.0026 & 0.330 \\
\hline 4.92 & 110 & 0.045 & 4.964 .58 & 0.0020 & 0.342 \\
\hline
\end{tabular}




\begin{tabular}{|c|c|c|c|c|c|}
\hline $\begin{array}{c}\text { Charge } \\
2200\end{array}$ & $\mathrm{~T}$ & B & v teori & $\begin{array}{c}(v t e- \\
\text { vex })^{\wedge} 2\end{array}$ & $\begin{array}{c}(\text { vavg- } \\
\text { vexp }^{\wedge} 2\end{array}$ \\
\hline 4.92 & 112 & 0.045 & 4.967 .63 & 0.0023 & 0.342 \\
\hline 4.93 & 114 & 0.045 & 4.970 .42 & 0.0016 & 0.354 \\
\hline 4.94 & 116 & 0.045 & 4.972 .96 & 0.0011 & 0.366 \\
\hline 4.94 & 118 & 0.045 & 4.975 .29 & 0.0012 & 0.366 \\
\hline 4.94 & 120 & 0.045 & 4.977 .42 & 0.0014 & 0.366 \\
\hline 4.95 & 122 & 0.045 & 4.979 .36 & 0.0009 & 0.378 \\
\hline 4.95 & 124 & 0.045 & 4.981 .14 & 0.0010 & 0.378 \\
\hline 4.95 & 126 & 0.045 & 4.982 .76 & 0.0011 & 0.378 \\
\hline 4.96 & 128 & 0.045 & 4.984 .24 & 0.0006 & 0.390 \\
\hline 4.96 & 130 & 0.045 & 4.985 .60 & 0.0007 & 0.390 \\
\hline 4.96 & 132 & 0.045 & 4.986 .84 & 0.0007 & 0.390 \\
\hline 4.96 & 134 & 0.045 & 4.987 .97 & 0.0008 & 0.390 \\
\hline 4.97 & 136 & 0.045 & 4.989 .01 & 0.0004 & 0.403 \\
\hline 4.97 & 138 & 0.045 & 4.989 .95 & 0.0004 & 0.403 \\
\hline 4.97 & 140 & 0.045 & 4.990 .82 & 0.0004 & 0.403 \\
\hline 4.97 & 142 & 0.045 & 4.991 .61 & 0.0005 & 0.403 \\
\hline 4.97 & 144 & 0.045 & 4.992 .33 & 0.0005 & 0.403 \\
\hline 4.97 & 146 & 0.045 & 4.992 .99 & 0.0005 & 0.403 \\
\hline 4.98 & 148 & 0.045 & 4.993 .59 & 0.0002 & 0.416 \\
\hline 4.98 & 150 & 0.045 & 4.994 .15 & 0.0002 & 0.416 \\
\hline 4.98 & 152 & 0.045 & 4.994 .65 & 0.0002 & 0.416 \\
\hline 4.98 & 154 & 0.045 & 4.995 .11 & 0.0002 & 0.416 \\
\hline 4.98 & 156 & 0.045 & 4.995 .53 & 0.0002 & 0.416 \\
\hline 4.98 & 158 & 0.045 & 4.995 .92 & 0.0003 & 0.416 \\
\hline 4.98 & 160 & 0.045 & 4.996 .27 & 0.0003 & 0.416 \\
\hline 4.98 & 162 & 0.045 & 4.996 .59 & 0.0003 & 0.416 \\
\hline 4.99 & 164 & 0.045 & 4.996 .88 & 0.0001 & 0.429 \\
\hline 4.99 & 166 & 0.045 & 4.997 .15 & 0.0001 & 0.429 \\
\hline 4.98 & 168 & 0.045 & 4.997 .40 & 0.0003 & 0.416 \\
\hline 4.99 & 170 & 0.045 & 4.997 .62 & 0.0001 & 0.429 \\
\hline 4.99 & 172 & 0.045 & 4.997 .82 & 0.0001 & 0.429 \\
\hline 4.99 & 174 & 0.045 & 4.998 .01 & 0.0001 & 0.429 \\
\hline 4.99 & 176 & 0.045 & 4.998 .18 & 0.0001 & 0.429 \\
\hline 4.99 & 178 & 0.045 & 4.998 .34 & 0.0001 & 0.429 \\
\hline 4.99 & 180 & 0.045 & 4.998 .48 & 0.0001 & 0.429 \\
\hline 4.99 & 182 & 0.045 & 4.998 .61 & 0.0001 & 0.429 \\
\hline 4.99 & 184 & 0.045 & 4.998 .73 & 0.0001 & 0.429 \\
\hline 4.99 & 186 & 0.045 & 4.998 .84 & 0.0001 & 0.429 \\
\hline 4.99 & 188 & 0.045 & 4.998 .94 & 0.0001 & 0.429 \\
\hline 4.99 & 190 & 0.045 & 4.999 .03 & 0.0001 & 0.429 \\
\hline 4.99 & 192 & 0.045 & 4.999 .12 & 0.0001 & 0.429 \\
\hline 4.99 & 194 & 0.045 & 4.999 .19 & 0.0001 & 0.429 \\
\hline 4.99 & 196 & 0.045 & 4.999 .26 & 0.0001 & 0.429 \\
\hline 5 & 198 & 0.045 & 4.999 .32 & 0.0001 & 0.442 \\
\hline 4.99 & 200 & 0.045 & 4.999 .38 & 0.0001 & 0.429 \\
\hline
\end{tabular}

\begin{tabular}{|c|c|c|c|c|c|}
\hline $\begin{array}{c}\text { Charge } \\
2200\end{array}$ & $\mathrm{~T}$ & B & $\mathrm{v}$ teori & $\begin{array}{c}(\text { vte- } \\
\text { vex })^{\wedge} 2\end{array}$ & $\begin{array}{l}(\text { vavg- } \\
\text { vexp)^2 }\end{array}$ \\
\hline 4.99 & 202 & 0.045 & 4.999 .44 & 0.0001 & 0.429 \\
\hline 5 & 204 & 0.045 & 4.999 .48 & 0.0001 & 0.442 \\
\hline 5 & 206 & 0.045 & 4.999.53 & 0.0001 & 0.442 \\
\hline $\bar{x}$ & & & & Jumlah & Jumlah \\
\hline 4.335 & & & & 2.4434 & 138.593 \\
\hline
\end{tabular}

Untuk menentukan nilai tegangan secara teori maka dapat menggunakan persamaan (4).

$$
b=\frac{1}{R C}
$$

Persamaan tersebut berasal dari rumus charging untuk proses pengisian, sesuai dengan persamaan (5)

$$
V_{c}=\varepsilon\left(1-e^{-t b}\right)
$$

Pada eksperimen ini diketahui nilai resistansi $R$ sebesar 10.000 ohm dan kapasitansinya secara teori (literatur) sebesar $2200 \mu \mathrm{F}$, maka nilai $b$ dapat ditentukan sesuai dengan persamaan (6)

$$
b=\frac{1}{10000 \times 2200 \times 10^{-6}}=0,045
$$

Untuk melihat keakuratan penentuan nilai tegangan eksperimen dengan teori, data diplotkan pada grafik yang ditunjukan pada Gambar 6.

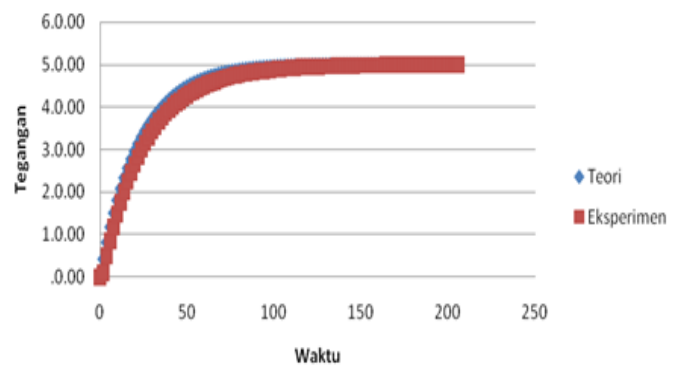

Gambar 6. Kurva tegangan terhadap waktu (pengisian kapasitor $2200 \mu \mathrm{F}$ )

Dari kurva tersebut dapat dilihat perbedaan antara tegangan secara eksperimen dan teori sangat sedikit untuk melihat nilai keakuratannya, maka dicari $\mathrm{R}^{2}$ dari kurva tersebut dengan menggunakan teorema fitting. Persamaan (7) merupakan hasil perhitungan $\mathrm{R}^{2}$ untuk melihat kesesuaian antara nilai teori dan nilai eksperimen.

$$
R^{2}=1-\frac{(v t e-v e x)^{\wedge} 2}{(\operatorname{vavg}-\operatorname{vexp})^{\wedge} 2}=0.98
$$

\section{Dapat dilihat dari $\mathrm{R}^{2}$ nya bahwa tegangan}


secara eksperimen sesuai dengan tegangan secara teori, hal ini menunjukkan metode ini dapat digunakan untuk menentukan kapasitansi suatu kapasitor. Berdasarkan nilai $\mathrm{R}^{2}$ di atas dapat dikatakan bahwa antara eksperimen dan teori hasilnya hampir mendekati nilai yang sama. Kemudian dicari nilai kapasitor secara eksperimen melalui persamaan (8).

$$
C=\frac{1}{R b}=2222 \mu F
$$

Semakin besar nilai kapasitor maka akan semakin banyak waktu yang dibutuhkan untuk mengisi kapasitor tersebut sampai mencapai 5 volt. Apabila semakin besar nilai kapasitansinya maka akan semakin kecil nilai tegangannya. Dalam pengujian ini dapat dibandingkan antara kapasitor dengan nilai

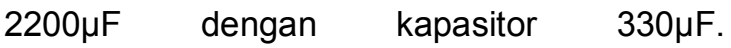
Pada Tabel 3 di bawah ini adalah hasil akuisisi data eksperimen dan teori untuk kapasitor $330 \mu \mathrm{F}$.

Tabel 3 Data Eksperimen pada Pengisian Kapasitor $330 \mu \mathrm{F}$

\begin{tabular}{|c|c|c|c|c|c|}
\hline $\begin{array}{c}\text { Charge } \\
330\end{array}$ & $\mathrm{~T}$ & $\mathrm{~B}$ & Vteori & $\begin{array}{c}\text { (vte- } \\
\text { vex) }\end{array}$ & $\begin{array}{c}\text { (vavg- } \\
\text { vexp) }\end{array}$ \\
\hline 0 & 0 & 0.303 & 0.000 & 0.000 & 16.903 \\
\hline 0 & 0 & 0.303 & 0.000 & 0.000 & 16.903 \\
\hline 1.31 & 2 & 0.303 & 2.272 & 0.926 & 7.847 \\
\hline 3 & 4 & 0.303 & 3.512 & 0.262 & 1.235 \\
\hline 3.89 & 6 & 0.303 & 4.188 & 0.089 & 0.049 \\
\hline 4.37 & 8 & 0.303 & 4.557 & 0.035 & 0.067 \\
\hline 4.64 & 10 & 0.303 & 4.758 & 0.014 & 0.279 \\
\hline 4.79 & 12 & 0.303 & 4.868 & 0.006 & 0.461 \\
\hline 4.87 & 14 & 0.303 & 4.928 & 0.003 & 0.576 \\
\hline 4.93 & 16 & 0.303 & 4.961 & 0.001 & 0.670 \\
\hline 4.95 & 18 & 0.303 & 4.979 & 0.001 & 0.703 \\
\hline 4.97 & 20 & 0.303 & 4.988 & 0.000 & 0.737 \\
\hline 4.98 & 22 & 0.303 & 4.994 & 0.000 & 0.755 \\
\hline 4.98 & 24 & 0.303 & 4.997 & 0.000 & 0.755 \\
\hline 4.99 & 26 & 0.303 & 4.998 & 0.000 & 0.772 \\
\hline 4.99 & 28 & 0.303 & 4.998 & 0.000 & 0.780 \\
\hline 4.99 & 30 & 0.303 & 4.998 & 0.000 & 0.787 \\
\hline 5 & 32 & 0.303 & 4.998 & 0.000 & 0.787 \\
\hline 5 & 34 & 0.303 & 4.999 & 0.000 & 0.790 \\
\hline $\bar{x}$ & & & & Jumlah & Jumlah \\
\hline 4.111 & & & 1.338 & 31.809 \\
\hline
\end{tabular}

Dari data tersebut dapat dilihat waktu pengisian pada kapasitor $2200 \mu \mathrm{F}$ lebih besar dibandingkan pada pengisian kapasitor $330 \mu \mathrm{F}$. Data tegangan eksperimen dan teori diplotkan kurva hubungan tegangan dan waktu pada Gambar 7.

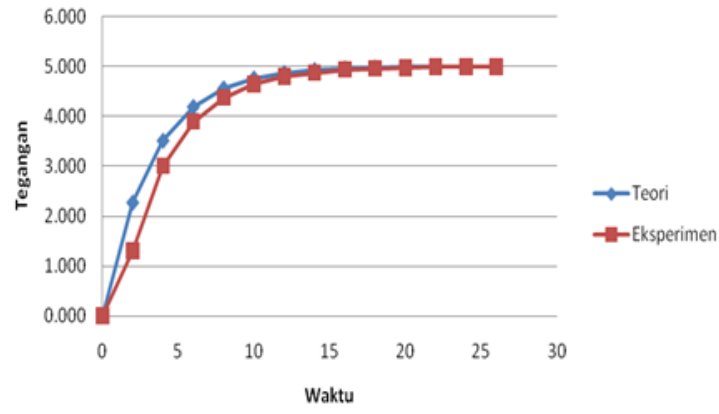

Gambar 7. Kurva tegangan terhadap waktu (pengisian kapasitor $330 \mu \mathrm{F}$ )

Berdasarkan hasil analisa data pada Tabel 2 dan Tabel 3 dapat dibandingkan bahwa kurva pengisian untuk kapasitor $2200 \mu \mathrm{F}$ membutuhkan waktu yang lebih lama untuk pengisian 5 volt dibandingkan kapasitor $330 \mu \mathrm{F}$. Berdasarkan hasil validasi dapat diperlihatkan bahwa kurva tersebut menunjukkan sedikit perbedaan antara tegangan yang dihasilkan secara eksperimen dan tegangan secara prediksi teori namun perbedaan tersebut tidak terlalu jauh. Seperti yang terlihat pada Tabel 4 di bawah ini dapat diperlihatkan tabel pengosongan kapasitor.

Tabel 4 Data Eksperimen pada Pengosongan Kapasitor $2200 \mu \mathrm{F}$

\begin{tabular}{|c|c|c|c|c|c|}
\hline $\begin{array}{c}\text { Discharge } \\
2200\end{array}$ & $\mathrm{~T}$ & $\mathrm{~B}$ & v teori & $\begin{array}{c}(\mathrm{vte}- \\
\text { vex)^2 }\end{array}$ & $\begin{array}{c}\text { (vavg- } \\
\text { vexp)^2 }\end{array}$ \\
\hline 5 & 0 & 0.045 & 5 & 0.0000 & 17.2697 \\
\hline 4.91 & 2 & 0.045 & 4.570 & 0.1158 & 16.5297 \\
\hline 4.52 & 4 & 0.045 & 4.176 & 0.1181 & 13.5106 \\
\hline 4.16 & 6 & 0.045 & 3.817 & 0.1177 & 10.9937 \\
\hline 3.83 & 8 & 0.045 & 3.488 & 0.1167 & 8.9143 \\
\hline 3.54 & 10 & 0.045 & 3.188 & 0.1238 & 7.2667 \\
\hline 3.26 & 12 & 0.045 & 2.914 & 0.1199 & 5.8355 \\
\hline 3.01 & 14 & 0.045 & 2.663 & 0.1204 & 4.6902 \\
\hline 2.77 & 16 & 0.045 & 2.434 & 0.1131 & 3.7082 \\
\hline 2.56 & 18 & 0.045 & 2.224 & 0.1127 & 2.9436 \\
\hline 2.36 & 20 & 0.045 & 2.033 & 0.1070 & 2.2973 \\
\hline 2.17 & 22 & 0.045 & 1.858 & 0.0974 & 1.7574 \\
\hline 2.01 & 24 & 0.045 & 1.698 & 0.0974 & 1.3588 \\
\hline & & & & & \\
\hline
\end{tabular}


42 | JIPFRI (Jurnal Inovasi Pendidikan Fisika dan Riset Ilmiah), Vol. 3 No. 1, Mei 2019

\begin{tabular}{|c|c|c|c|c|c|}
\hline $\begin{array}{c}\text { Discharge } \\
2200 \\
\end{array}$ & $\mathrm{~T}$ & $B$ & v teori & $\begin{array}{c}\text { (vte- } \\
\text { vex }{ }^{\wedge} 2\end{array}$ & $\begin{array}{c}\text { (vavg- } \\
\text { vexp)^2 }\end{array}$ \\
\hline 1.85 & 26 & 0.045 & 1.552 & 0.0889 & 1.0114 \\
\hline 1.71 & 28 & 0.045 & 1.418 & 0.0851 & 0.7494 \\
\hline 1.58 & 30 & 0.045 & 1.296 & 0.0805 & 0.5412 \\
\hline 1.46 & 32 & 0.045 & 1.185 & 0.0758 & 0.3791 \\
\hline 1.34 & 34 & 0.045 & 1.083 & 0.0662 & 0.2457 \\
\hline 1.24 & 36 & 0.045 & 0.989 & 0.0628 & 0.1566 \\
\hline 1.15 & 38 & 0.045 & 0.904 & 0.0604 & 0.0934 \\
\hline 1.06 & 40 & 0.045 & 0.826 & 0.0545 & 0.0465 \\
\hline 0.98 & 42 & 0.045 & 0.755 & 0.0505 & 0.0184 \\
\hline 0.91 & 44 & 0.045 & 0.690 & 0.0482 & 0.0043 \\
\hline 0.84 & 46 & 0.045 & 0.631 & 0.0437 & 0.0001 \\
\hline 0.78 & 48 & 0.045 & 0.577 & 0.0414 & 0.0041 \\
\hline 0.72 & 50 & 0.045 & 0.527 & 0.0373 & 0.0155 \\
\hline 0.66 & 52 & 0.045 & 0.482 & 0.0318 & 0.0340 \\
\hline 0.61 & 54 & 0.045 & 0.440 & 0.0288 & 0.0549 \\
\hline 0.57 & 56 & 0.045 & 0.402 & 0.0281 & 0.0753 \\
\hline 0.52 & 58 & 0.045 & 0.368 & 0.0232 & 0.1052 \\
\hline 0.48 & 60 & 0.045 & 0.336 & 0.0207 & 0.1327 \\
\hline 0.45 & 62 & 0.045 & 0.307 & 0.0204 & 0.1555 \\
\hline 0.42 & 64 & 0.045 & 0.281 & 0.0194 & 0.1800 \\
\hline 0.39 & 66 & 0.045 & 0.257 & 0.0178 & 0.2064 \\
\hline 0.36 & 68 & 0.045 & 0.234 & 0.0158 & 0.2346 \\
\hline 0.33 & 70 & 0.045 & 0.214 & 0.0134 & 0.2645 \\
\hline 0.3 & 72 & 0.045 & 0.196 & 0.0109 & 0.2963 \\
\hline 0.28 & 74 & 0.045 & 0.179 & 0.0102 & 0.3185 \\
\hline 0.26 & 76 & 0.045 & 0.164 & 0.0093 & 0.3414 \\
\hline 0.24 & 78 & 0.045 & 0.149 & 0.0082 & 0.3652 \\
\hline 0.22 & 80 & 0.045 & 0.137 & 0.0070 & 0.3898 \\
\hline 0.21 & 82 & 0.045 & 0.125 & 0.0072 & 0.4024 \\
\hline 0.2 & 84 & 0.045 & 0.114 & 0.0074 & 0.4151 \\
\hline 0.18 & 86 & 0.045 & 0.104 & 0.0057 & 0.4413 \\
\hline 0.17 & 88 & 0.045 & 0.095 & 0.0056 & 0.4547 \\
\hline 0.15 & 90 & 0.045 & 0.087 & 0.0040 & 0.4821 \\
\hline 0.14 & 92 & 0.045 & 0.080 & 0.0036 & 0.4961 \\
\hline 0.13 & 94 & 0.045 & 0.073 & 0.0033 & 0.5103 \\
\hline 0.12 & 96 & 0.045 & 0.066 & 0.0029 & 0.5246 \\
\hline 0.11 & 98 & 0.045 & 0.061 & 0.0024 & 0.5392 \\
\hline 0.1 & 100 & 0.045 & 0.056 & 0.0020 & 0.5540 \\
\hline 0.09 & 102 & 0.045 & 0.051 & 0.0015 & 0.5690 \\
\hline 0.09 & 104 & 0.045 & 0.046 & 0.0019 & 0.5690 \\
\hline 0.08 & 106 & 0.045 & 0.042 & 0.0014 & 0.5842 \\
\hline 0.07 & 108 & 0.045 & 0.039 & 0.0010 & 0.5996 \\
\hline 0.07 & 110 & 0.045 & 0.035 & 0.0012 & 0.5996 \\
\hline 0.06 & 112 & 0.045 & 0.032 & 0.0008 & 0.6152 \\
\hline
\end{tabular}

\begin{tabular}{|c|c|c|c|c|c|}
\hline $\begin{array}{c}\text { Discharge } \\
2200 \\
\end{array}$ & $\mathrm{~T}$ & B & $v$ teori & $\begin{array}{c}(\text { vte- } \\
\text { vex })^{\wedge} 2\end{array}$ & $\begin{array}{c}\text { (vavg- } \\
\text { vexp)^2 }\end{array}$ \\
\hline 0.06 & 114 & 0.045 & 0.030 & 0.0009 & 0.6152 \\
\hline 0.05 & 116 & 0.045 & 0.027 & 0.0005 & 0.6309 \\
\hline 0.05 & 118 & 0.045 & 0.025 & 0.0006 & 0.6309 \\
\hline 0.05 & 120 & 0.045 & 0.023 & 0.0008 & 0.6309 \\
\hline 0.04 & 122 & 0.045 & 0.021 & 0.0004 & 0.6469 \\
\hline 0.04 & 124 & 0.045 & 0.019 & 0.0004 & 0.6469 \\
\hline 0.04 & 126 & 0.045 & 0.017 & 0.0005 & 0.6469 \\
\hline 0.04 & 128 & 0.045 & 0.016 & 0.0006 & 0.6469 \\
\hline 0.03 & 130 & 0.045 & 0.014 & 0.0002 & 0.6631 \\
\hline 0.03 & 132 & 0.045 & 0.013 & 0.0003 & 0.6631 \\
\hline 0.02 & 134 & 0.045 & 0.012 & 0.0001 & 0.6795 \\
\hline 0.02 & 136 & 0.045 & 0.011 & 0.0001 & 0.6795 \\
\hline 0.02 & 138 & 0.045 & 0.010 & 0.0001 & 0.6795 \\
\hline 0.02 & 140 & 0.045 & 0.009 & 0.0001 & 0.6795 \\
\hline 0.02 & 142 & 0.045 & 0.008 & 0.0001 & 0.6795 \\
\hline 0.01 & 144 & 0.045 & 0.008 & 0.0001 & 0.6961 \\
\hline 0.01 & 146 & 0.045 & 0.007 & 0.0001 & 0.6961 \\
\hline 0.01 & 148 & 0.045 & 0.006 & 0.0001 & 0.6961 \\
\hline 0.01 & 150 & 0.045 & 0.006 & 0.0001 & 0.6961 \\
\hline 0.01 & 152 & 0.045 & 0.005 & 0.0001 & 0.6961 \\
\hline 0.01 & 154 & 0.045 & 0.005 & 0.0001 & 0.6961 \\
\hline 0.01 & 156 & 0.045 & 0.004 & 0.0001 & 0.6961 \\
\hline 0.01 & 158 & 0.045 & 0.004 & 0.0001 & 0.6961 \\
\hline 0 & 160 & 0.045 & 0.004 & 0.0001 & 0.7129 \\
\hline $\bar{x}$ & & & & Jumlah & Jumlah \\
\hline 0.844 & & & & 2.4781 & 110.6833 \\
\hline
\end{tabular}

Berikut ini adalah grafik hubungan waktu dan tegangan proses pengosongan kapasitor $2200 \mu \mathrm{F}$ yang ditunjukkan pada Gambar 8 .

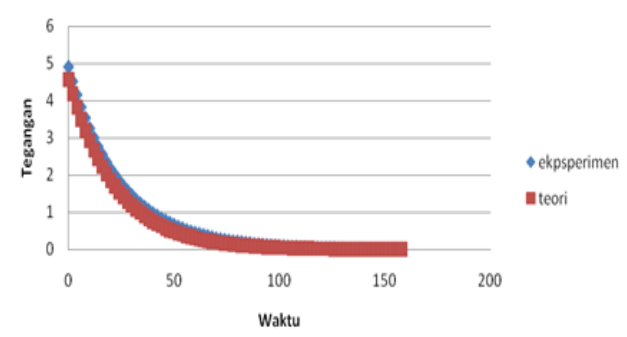

Gambar 8. Kurva tegangan terhadap waktu (pengosongan kapasitor $2200 \mu \mathrm{F}$ )

Dari data tabel di atas didapatkan $\mathrm{R}^{2}$ sebesar 0.98, hasil tersebut menunjukkan kesesuaian antara tegangan eksperimen dan tegangan teori yang didapat melalui persamaan discharge yang sangat baik dan menghasilkan kapasitor $2222 \mu \mathrm{F}$, hal tersebut menunjukkan 
sedikit perbedaan dengan kapasitansi prediksi pada kapasitor $2200 \mu \mathrm{F}$ namun hasil yang diperoleh masih tidak jauh berbeda dengan kapasitor yang sebenarnya. Tabel 5 adalah data pengosongan kapasitor $330 \mu \mathrm{F}$.

Tabel 5 Data Eksperimen pada Pengosongan Kapasitor $330 \mu \mathrm{F}$

\begin{tabular}{|c|c|c|c|c|c|}
\hline $\begin{array}{c}\text { Discharge } \\
330\end{array}$ & $\mathrm{~T}$ & $\mathrm{~B}$ & Vteori & $\begin{array}{c}\text { (vte- } \\
\text { vex })^{\wedge} 2\end{array}$ & $\begin{array}{c}\text { (vavg- } \\
\text { vexp })^{\wedge}\end{array}$ \\
\hline 5 & 0 & 0.303 & 5.00 & 0.000000 & 12.051 \\
\hline 2.91 & 2 & 0.303 & 2.73 & 0.033254 & 1.908 \\
\hline 1.58 & 4 & 0.303 & 1.49 & 0.008463 & 0.003 \\
\hline 0.87 & 6 & 0.303 & 0.81 & 0.003393 & 0.434 \\
\hline 0.47 & 8 & 0.303 & 0.44 & 0.000738 & 1.121 \\
\hline 0.26 & 10 & 0.303 & 0.24 & 0.000339 & 1.609 \\
\hline 0.15 & 12 & 0.303 & 0.13 & 0.000332 & 1.900 \\
\hline 0.08 & 14 & 0.303 & 0.07 & 0.000066 & 2.098 \\
\hline 0.05 & 16 & 0.303 & 0.04 & 0.000116 & 2.186 \\
\hline 0.02 & 18 & 0.303 & 0.02 & 0.000002 & 2.276 \\
\hline 0.01 & 20 & 0.303 & 0.01 & 0.000003 & 2.306 \\
\hline 0 & 22 & 0.303 & 0.01 & 0.000041 & 2.337 \\
\hline $\bar{x}$ & & & & Jumlah & Jumlah \\
\hline 0.95 & & & & 0.046746 & 30.229 \\
\hline
\end{tabular}

Dari data tersebut didapatkan nilai $\mathrm{R}^{2}$ sebesar 0.99 serta dapat dilihat dari grafik yang tunjukan pada Gambar 9 di bawah ini kurva pengosongan kapasitor $330 \mu \mathrm{F}$.

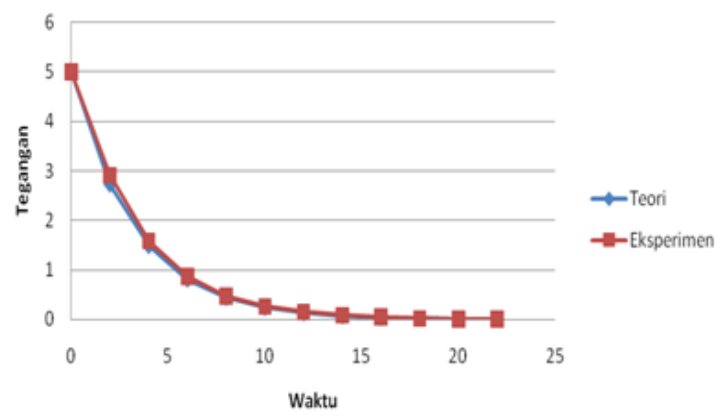

Gambar 9. Kurva tegangan terhadap waktu (pengosongan kapasitor $330 \mu \mathrm{F}$ )

Berdasarkan kurva pada Gambar 9 dapat dilihat kesesuaian hasil antara eksperimen dan teori yang mendekati sama (dengan nilai $R^{2}$ dapat dilihat pada Tabel 6), namun masih terdapat perbedaan yang sangat kecil sehingga masih dapat dikatakan memiliki hasil yang cukup akurat untuk mendapatkan nilai kapasitor sebesar $330 \mu \mathrm{F}$.

Tabel 6. Nilai $R^{2}$ antara eksperimen dan teori

\begin{tabular}{|l|l|c|}
\hline \multirow{3}{*}{ Kapasitor } & \multicolumn{2}{|c|}{$\mathrm{R}^{2}$} \\
\cline { 2 - 3 } & $\begin{array}{c}\text { Proses } \\
\text { Charging }\end{array}$ & $\begin{array}{c}\text { Proses } \\
\text { Discharging }\end{array}$ \\
\hline $2200 \mu \mathrm{F}$ & 0.98 & 0.98 \\
\hline $330 \mu \mathrm{F}$ & 0.96 & 0.99 \\
\hline
\end{tabular}

\section{PENUTUP}

Berdasarkan dasar teori serta hasil dan pembahasan pada penelitian ini, maka telah berhasil ditentukan jumlah kapasitansi muatan pada kapasitor, serta telah berhasil dibandingkan kapasitansi muatan pada kapasitor secara eksperimen dan prediksi teori. Pada penelitian ini didapatkan kesesuaian hasil antara eksperimen dan teori (nilai $\mathrm{R}^{2}$ pada pengisian dan pengosongan lebih besar dari 0,95)

\section{UCAPAN TERIMA KASIH}

Ucapan terima kasih ditujukan kepada Lab. Fisika-Mekatronika Politeknik STTT Bandung, serta rekan-rekan dosen Politeknik STTT Bandung yang telah memberikan dukungan pada penelitian ini.

\section{DAFTAR PUSTAKA}

Allagui, A., Elwakil, A. S., Fouda, M. E., \& Radwan, A. G. (2018). Capacitive behavior and stored energy in supercapacitors at power line frequencies. Journal of Power Sources, 390,142-147.

https://doi.org/10.1016/j.jpowsour.2018 .04 .035

Arshad, A., Khan, S., Alam, A. H. M. Z., Tasnim, R., Gunawan, T. S., Ahmad, R., \& Nataraj, C. (2016). An activity monitoring system for senior citizens living independently using capacitive sensing technique. In IEEE International Instrumentation and Measurement Technology Conference Proceedings.

https://doi.org/10.1109//2MTC.2016.75 $\underline{20405}$ 
Badamasi, Y. A. (2014). The working principle of an Arduino. In 11th International Conference on Electronics, Computer and Computation (ICECCO). https://doi.org/10.1109/ICECCO.2014. $\underline{6997578}$

Cheng, J., Amft, O., Bahle, G., \& Lukowicz, P. (2013). Designing Sensitive Wearable Capacitive Sensors for Activity Recognition. IEEE Sensors Journal, 13(10), 3935-3947. https://doi.org/10.1109/JSEN.2013.225 $\underline{9693}$

Coyle, S., King-Tong Lau, Moyna, N., O'Gorman, D., Diamond, D., Di Francesco, F., Costanzo, D., Salvo, P., Trivella, M.G., De Rossi, D.E., Taccini, N., Paradiso, R., Porchet, J.A., Ridolfi, A., Luprano, J., Chuzel, C., Lanier, T., Cavalier, R., Schoumacker, S., Mourier, V., Chartier, I., Convert, R., De Moncuit, H., \& Bini, C. (2010). BIOTEX-Biosensing Textiles for Personalised Healthcare Management. IEEE Transactions on Information Technology in Biomedicine, 14(2), 364-370.

https://doi.org/10.1109/TITB.2009.203 $\underline{8484}$

Dean, R. N., \& Rane, A. K. (2013). A Digital Frequency-Locked Loop System for Capacitance Measurement. IEEE Transactions on Instrumentation and Measurement, 62(4), 777-784. https://doi.org/10.1109/TIM.2013.2240 092

González, T.J., Torres, S.R., Blaya, R.P., Toledo, M.A., Jiménez, B.M., \& Soto, V.F. (2019). Design and Calibration of a Low-Cost SDI-12 Soil Moisture Sensor. Sensors, 19(3), 491. https://doi.org/10.3390/s19030491

Halliday, D., Resnick, R., Walker. (1997). Fundamentals of Physics-Extended, $5^{\text {th }}$, John Wiley \& Sons, New York.

Hoffmann, T., Eilebrecht, B., \& Leonhardt, S.
(2011). Respiratory Monitoring System on the Basis of Capacitive Textile Force Sensors. IEEE Sensors Journal, 11(5), 1112-1119.

https://doi.org/10.1109/JSEN.2010.208 2524

Kondalkar, V. V., Ryu, G., Lee, Y., \& Lee, K. (2019). Development of highly sensitive and stable humidity sensor for real-time monitoring of dissolved moisture in transformer-insulating oil. Sensors and Actuators B: Chemical, 286, 377-385. https://doi.org/10.1016/i.snb.2019.01.1 $\underline{62}$

Laflamme, S., Saleem, H. S., Vasan, B. K., Geiger, R. L., Chen, D., Kessler, M. R., \& Rajan, K. (2013). Soft Elastomeric Capacitor Network for Strain Sensing Over Large Surfaces. IEEE/ASME Transactions on Mechatronics, 18(6), 1647-1654.

https://doi.org/10.1109/TMECH.2013.2 $\underline{283365}$

Laflamme, S., Ubertini, F., Saleem, H., D'Alessandro, A., Downey, A., Ceylan, H., \& Materazzi, A. L. (2015). Dynamic Characterization of a Soft Elastomeric Capacitor for Structural Health Monitoring. Journal of Structural Engineering, 141(8), 04014186. https://ascelibrary.org/doi/abs/10.1061/ (ASCE)ST.1943-541X.0001151

Lee, H. J., Hwang, S. H., Yoon, H. N., Lee, W. K., \& Park, K. S. (2015). Heart Rate Variability Monitoring during Sleep Based on Capacitively Coupled Textile Electrodes on a Bed. Sensors, 15(5), 11295-11311. https://doi.org/10.3390/s150511295

Mukhopadhyay, S. C. (2015). Wearable Sensors for Human Activity Monitoring: A Review. IEEE Sensors Journal, 15(3), $\quad 1321-1330$. https://doi.org/10.1109/JSEN.2014.237 $\underline{0945}$ 
Min, S.D., Yun, Y., \& Shin, H. (2014). Simplified Structural Textile Respiration Sensor Based on Capacitive Pressure Sensing Method. IEEE Sensors Journal, 14(9), 3245-3251.

https://doi.org/10.1109/JSEN.2014.232 $\underline{7991}$

Putra, V.G.V., Ngadiono, \& Purnomosari, E. (2016). Pengantar Listrik Magnet dan Terapannya. Yogyakarta: CV. Mulia Jaya.

Salvo, P., Di Francesco, F., Costanzo, D., Ferrari, C., Trivella, M. G., \& De Rossi, D. (2010). A Wearable Sensor for Measuring Sweat Rate. IEEE Sensors Journal, 10(10), 1557-1558. https://doi.org/10.1109/JSEN.2010.204 $\underline{6634}$

Tang, X., Li, S., Shen, L., Zhao, W., Yang, X., Williams, R., Liu, J., Tan, Z., Hall, N. \& Sun, N. (2019). $18.2 \quad$ A 16fJ/Conversion-Step Time-Domain Two-Step Capacitance-to-Digital Converter. In 2019 IEEE International Solid- State Circuits Conference (ISSCC).

https://doi.org/10.1109/ISSCC.2019.86 $\underline{62359}$

Xia, J., Chen, F., Li, J., \& Tao, N. (2009). Measurement of the quantum capacitance of graphene. Nature Nanotechnology, 4(8), 505-509. https://doi.org/10.1038/nnano.2009.17 $\underline{7}$ 